\title{
BUILDING BRIDGES FOR INNOVATION IN AGEING : SYNERGIES BETWEEN ACTION GROUPS OF THE EIP ON AHA
}

\section{Bousquet, J.}

2017-01

Bousquet , J , Bewick, M , Cano , A , Eklund , P , Fico , G, Goswami , N , Guldemond , N A , Henderson, D , Hinkema , M J , Liotta , G , Mair , A, Molloy , W , Monaco , A , Monsonis-Paya , I , Nizinska , A , Papadopoulos, H, Pavlickova , A, Pecorelli , S , Prados-Torres, A , Roller-Wirnsberger, R E , Somekh, D, Vera-Munoz , C, Visser , F , Farrell , J , Malva , J , Ranberg , K A , Camuzat , T , Carriazo , A M , Crooks , G, Gutter , Z , laccarino , G, Manuel De Keenoy, E, Moda , G, Rodriguez-Manas , L, Vontetsianos , T , Abreu , C , Alonso , J , Alonso-Bouzon , C , Ankri , J, Arredondo , M T, Avolio , F , Bedbrook, A, Bialoszewski, A Z, Blain, H, Bourret, $R$, Cabrera-Umpierrez, M F , Catala , A , O'Caoimh, R, Cesari, M , Chavannes, N H, Correia-Da-Sousa, J, Dedeu , T , Ferrando, M , Ferri , M , Fokkens, W J, Garcia-Lizana, F, Guerin , O , Hellings , P W , Haahtela , T , Illario , M , Inzerilli , M C , Carlsen, K C L, Kardas , P , Keil , T , Maggio , M , Mendez-Zorrilla , A, Menditto , E, Mercier, J , Michel , J P, Murray , R, Nogues , M , O'Byrne-Maguire , I, Pappa, D , Parent , A S , Pastorino , M , Robalo-Cordeiro , C , Samolinski, B , Siciliano, P, Teixeira, A M , Tsartara, S I, Valiulis, A, Vandenplas, O, Vasankari, T, Vellas, B, Vollenbroek-Hutten, M , Wickman, M , Yorgancioglu, A , Zuberbier , T , Barbagallo , M , Canonica, G W , Klimek , L , Maggi , S , Aberer , W , Akdis , C , Adcock , I M , Agache , I , Albera , C , Alonso-Trujillo , F , Angel Guarcia , M , Annesi-Maesano , I, Apostolo , J , Arshad, S H, Attalin , V , Avignon , A, Bachert , C , Baroni , I, Bel , E , Benson, M , Bescos , C , Blasi , F , Barbara , C , Bergmann , K C , Bernard, P L, Bonini, S, Bousquet, P J , Branchini, B, Brightling , C E , Bruguiere , V , Bunu, C , Bush , A, Caimmi , D P , Calderon, M A, Canovas , G, Cardona , V , Carlsen , $\mathrm{KH}$, Cesario , A, Chkhartishvili, $E$, Chiron, $R$, Chivato , $T$, Chung, $K F$, D'Angelantonio , M, De Carlo , G, Cholley , D, Chorin, F , Combe , B , Compas , B , Costa, D J , Costa , E, Coste , O, Coupet, A -L, Crepaldi , G, Custovic , A, Dahl, R, Dahlen, S E , Demoly , $P$, Devillier , P , Didier , A , Dinh-Xuan , A T , Djukanovic , R , Dokic , D , Du Toit , G , Dubakiene, R, Dupeyron, A, Emuzyte , R, Fiocchi , A, Wagner , A, Fletcher, M , Fonseca , J Fougere , B , Gamkrelidze , A, Garces , G, Garcia-Aymeric , J , Garcia-Zapirain , B , Gemicioglu , B , Gouder , C , Hellquist-Dahl , B , Hermosilla-Gimeno , I , Heve , D , Holland, C, Humbert, M , Hyland , M, Johnston, S L , Just, J , Jutel , M , Kaidashev , I P , Khaitov, M , Kalayci, O , Kalyoncu, A F , Keijser , W , Kerstjens , H , Knezovic, J , Kowalski, M, Koppelman, G H , Kotska , T, Kovac , M , Kull , I, Kuna , P , Kvedariene, V , Lepore, V , Macnee , W , Maggio, M , Magnan , A, Majer , I, Manning , P , Marcucci, M , Marti , T, Masoli , M, Melen , E, Miculinic , N, Mihaltan , F, Milenkovic , B , 


\section{BUILDING BRIDGES FOR INNOVATION IN AGEING: SYNERGIES BETWEEN ACTION GROUPS OF THE EIP ON AHA}

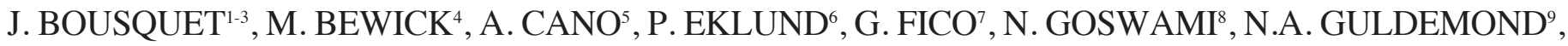

D. HENDERSON ${ }^{10}$, M.J. HINKEMA ${ }^{11}$, G. LIOTTA ${ }^{12}$, A. MAIR ${ }^{13}$, W. MOLLOY ${ }^{14}$, A. MONACO ${ }^{15}$,

I. MONSONIS-PAYA ${ }^{16}$, A. NIZINSKA ${ }^{17}$, H. PAPADOPOULOS ${ }^{18}$, A. PAVLICKOVA $^{10}$, S. PECORELLI $^{19}$,

A. PRADOS-TORRES ${ }^{20}$, R.E. ROLLER-WIRNSBERGER ${ }^{8}$, D. SOMEKH ${ }^{21}$, C. VERA-MUÑOZ ${ }^{7}$,

F. VISSER ${ }^{22}$, J. FARRELL ${ }^{23}$, J. MALVA $^{24}$, K. ANDERSEN RANBERG ${ }^{25}$, T. CAMUZAT ${ }^{2,26}$,

A.M. CARRIAZO ${ }^{27}$, G. CROOKS ${ }^{10}$, Z. GUTTER ${ }^{28}$, G. IACCARINO ${ }^{29}$, E. MANUEL DE KEENOY ${ }^{30}$,

G. MODA ${ }^{31}$, L. RODRIGUEZ-MAÑAS ${ }^{32}$, T. VONTETSIANOS ${ }^{33}$, C. ABREU ${ }^{34}$, J. ALONSO $^{35}$,

C. ALONSO-BOUZON ${ }^{32}$, J. ANKRI ${ }^{3}$, M.T. ARREDONDO ${ }^{7}$, F. AVOLIO ${ }^{36}$, A. BEDBROOK ${ }^{2}$,

A.Z. BIAŁOSZEWSKI ${ }^{37}$, H. BLAIN ${ }^{2,38,39}$, R. BOURRET ${ }^{2,40}$, M.F. CABRERA-UMPIERREZ ${ }^{7,41}$, A. CATALA $^{42}$,

R. O'CAOIMH ${ }^{14}$, M. CESARI ${ }^{43}$, N.H. CHAVANNES ${ }^{44}$, J. CORREIA-DA-SOUSA ${ }^{45}$, T. DEDEU ${ }^{46}$,

M. FERRANDO ${ }^{47}$, M. FERRI ${ }^{16}$, W.J. FOKKENS ${ }^{48}$, F. GARCIA-LIZANA ${ }^{49}$, O. GUÉRIN ${ }^{50}$, P.W. HELLINGS ${ }^{51}$,

T. HAAHTELA ${ }^{52}$, M. ILLARIO ${ }^{53}$, M.C. INZERILLI ${ }^{54}$, K.C. LODRUP CARLSEN ${ }^{55}$, P. KARDAS ${ }^{56}$, T. KEIL $^{57}$,

M. MAGGIO ${ }^{58}$, A. MENDEZ-ZORRILLA ${ }^{59}$, E. MENDITTO $^{60}$, J. MERCIER $^{2,61}$, J.P. MICHEL ${ }^{62}$,

R. MURRAY ${ }^{63}$, M. NOGUES ${ }^{2,64}$, I. O'BYRNE-MAGUIRE ${ }^{65}$, D. PAPPA ${ }^{18}$, A.S. PARENT ${ }^{66}$, M. PASTORINO $^{7}$,

C. ROBALO-CORDEIRO ${ }^{67}$, B. SAMOLINSKI ${ }^{68}$, P. SICILIANO $^{69}$, A.M. TEIXEIRA ${ }^{70}$, S.I. TSARTARA ${ }^{71}$,

A. VALIULIS ${ }^{72,73}$, O. VANDENPLAS ${ }^{74}$, T. VASANKARI ${ }^{75}$, B. VELLAS $^{43}$, M. VOLLENBROEK-HUTTEN $^{76}$,

M. WICKMAN ${ }^{77}$, A. YORGANCIOGLU ${ }^{78}$, T. ZUBERBIER ${ }^{79}$, M. BARBAGALLO ${ }^{80}$, G.W. CANONICA ${ }^{81}$,

L. KLIMEK ${ }^{82}$, S. MAGGI ${ }^{83}$, W. ABERER ${ }^{84}$, C. AKDIS ${ }^{85}$, I.M. ADCOCK ${ }^{86}$, I. AGACHE A $^{87}$, C. ALBERA ${ }^{88}$,

F. ALONSO-TRUJILLO ${ }^{89}$, M. ANGEL GUARCIA ${ }^{5}$, I. ANNESI-MAESANO ${ }^{90}$, J. APOSTOLO $^{34}$,

S.H. ARSHAD ${ }^{91}$, V . ATTALIN ${ }^{92}$, A. AVIGNON ${ }^{93}$, C. BACHERT ${ }^{94}$, I. BARONI ${ }^{95}$, E. BEL ${ }^{96}$, M. BENSON $^{97}$,

C. BESCOS $^{98}$, F. BLASI ${ }^{99}$, C. BARBARA ${ }^{100}$, K.C. BERGMANN ${ }^{79}$, P.L. BERNARD ${ }^{39}$, S. BONINI ${ }^{101}$,

P.J. BOUSQUET ${ }^{90}$, B. BRANCHINI ${ }^{16}$, C.E. BRIGHTLING ${ }^{102}$, V. BRUGUIËRE ${ }^{64}$, C. BUNU ${ }^{103}$,

A. BUSH ${ }^{104}$, D.P. CAIMMI ${ }^{105}$, M.A. CALDERON ${ }^{106}$, G. CANOVAS ${ }^{107}$, V . CARDONA ${ }^{108}$, K.H. CARLSEN ${ }^{109}$,

A. CESARIO ${ }^{110}$, E. CHKHARTISHVILI ${ }^{111}$, R. CHIRON ${ }^{105}$, T. CHIVATO ${ }^{112}$, K.F. CHUNG $^{113}$,

M. D'ANGELANTONIO ${ }^{114}$, G. DE CARLO ${ }^{115}$, D. CHOLLEY ${ }^{116}$, F. CHORIN $^{117}$, B. COMBE ${ }^{118}$,

B. COMPAS ${ }^{119}$, D.J. COSTA ${ }^{2}$, E. COSTA ${ }^{120}$, O. COSTE $^{121}$, A.-L. COUPET ${ }^{64}$, G. CREPALDI $^{122}$,

A. CUSTOVIC ${ }^{123}$, R. DAHL ${ }^{124}$, S.E. DAHLEN ${ }^{125}$, P. DEMOLY $^{90,105}$, P. DEVILLIER $^{126}$, A. DIDIER ${ }^{127}$,

A.T. DINH-XUAN ${ }^{128}$, R. DJUKANOVIC ${ }^{129}$, D. DOKIC ${ }^{130}$, G. DU TOIT ${ }^{131}$, R. DUBAKIENE $^{132}$,

A. DUPEYRON ${ }^{39,133}$, R. EMUZYTE ${ }^{134}$, A. FIOCCHI ${ }^{135}$, A. WAGNER ${ }^{136}$, M. FLETCHER $^{137}$,

J. FONSECA ${ }^{138}$, B. FOUGÈRE ${ }^{43}$, A. GAMKRELIDZE ${ }^{139}$, G. GARCES ${ }^{16}$, J. GARCIA-AYMERIC $^{140}$,

B. GARCIA-ZAPIRAIN ${ }^{141}$, B. GEMICIOĞLU ${ }^{142}$, C. GOUDER ${ }^{143}$, B. HELLQUIST-DAHL ${ }^{144}$,

I. HERMOSILLA-GIMENO ${ }^{145}$, D. HÉVE ${ }^{146}$, C. HOLLAND ${ }^{147}$, M. HUMBERT $^{148}$, M. HYLAND ${ }^{149}$,

S.L. JOHNSTON ${ }^{150}$, J. JUST ${ }^{151}$, M. JUTEL ${ }^{152}$, I.P. KAIDASHEV ${ }^{153}$, M. KHAITOV $^{154}$, O. KALAYCI ${ }^{155}$,

A.F. KALYONCU ${ }^{156}$, W. KEIJSER ${ }^{157}$, H. KERSTJENS ${ }^{158}$, J. KNEZOVIĆ ${ }^{159}$, M. KOWALSKI ${ }^{160}$,

G.H. KOPPELMAN ${ }^{161}$, T. KOTSKA ${ }^{162}$, M. KOVAC ${ }^{159}$, I. KULL ${ }^{77}$, P. KUNA ${ }^{163}$, V. KVEDARIENE ${ }^{164}$,

V. LEPORE ${ }^{165}$, W. MACNEE ${ }^{166}$, M. MAGGIO ${ }^{58}$, A. MAGNAN ${ }^{167}$, I. MAJER $^{168}$, P. MANNING $^{169}$,

M. MARCUCCI ${ }^{170}$, T. MARTI ${ }^{171}$, M. MASOLI ${ }^{149}$, E. MELEN $^{172}$, N. MICULINIC ${ }^{173}$, F. MIHALTAN ${ }^{174}$, B. MILENKOVIC ${ }^{175}$, J. MILLOT-KEURINCK $^{64}$, H. MLINARIĆ ${ }^{159}$, I. MOMAS $^{176,177}$, S. MONTEFORT $^{178}$,

M. MORAIS-ALMEIDA ${ }^{179,180}$, T. MORENO-CASBAS ${ }^{181}$, R. MÖSGES ${ }^{182}$, J. MULLOL $^{183}$, R. NADIF $^{3}$,

M. NALIN ${ }^{95}$, E. NAVARRO-PARDO ${ }^{5,184}$, K. NEKAM ${ }^{185}$, G. NINOT $^{186}$, D. PACCARD $^{64}$, S. PAIS $^{187}$,

E. PALUMMERI ${ }^{188}$, P. PANZNER ${ }^{189}$, N.K. PAPADOPOULOS ${ }^{190}$, C. PAPANIKOLAOU $^{191}$,

G. PASSALACQUA ${ }^{81}$, E. PASTOR ${ }^{192,193}$, M. PERROT ${ }^{194}$, D. PLAVEC ${ }^{195}$, T.A. POPOV ${ }^{196}$, D.S. POSTMA ${ }^{197}$, 
D. PRICE ${ }^{198}$, N. RAFFORT ${ }^{199}$, J.C. REUZEAU ${ }^{64}$, J.M. ROBINE ${ }^{200}$, F. RODENAS ${ }^{201}$, F. ROBUSTO ${ }^{165}$, N. ROCHE ${ }^{202}$, A. ROMANO ${ }^{203}$, V. ROMANO ${ }^{204}$, J. ROSADO-PINTO $^{205}$, F. ROUBILLE ${ }^{2.206}$, F. RUIZ $^{5}$, D. RYAN ${ }^{207}$, T. SALCEDO ${ }^{208}$, P. SCHMID-GRENDELMEIER ${ }^{209}$, H. SCHULZ ${ }^{210}$, H.J. SCHUNEMANN ${ }^{211}$, E. SERRANO ${ }^{212}$, A. SHEIKH ${ }^{213}$, M. SHIELDS ${ }^{214}$, N. SIAFAKAS ${ }^{215}$, N. SCICHILONE ${ }^{216}$, P. SICILIANO ${ }^{69}$, I. SKRINDO ${ }^{217}$, H.A. SMIT ${ }^{218}$, S. SOURDET ${ }^{43}$, E. SOUSA-COSTA ${ }^{219}$, O. SPRANGER ${ }^{136}$, T. SOORONBAEV ${ }^{220}$, V. SRUK ${ }^{159}$, P.J. STERK ${ }^{221}$, A. TODO-BOM ${ }^{22}$, J. TOUCHON $^{223}$, D. TRAMONTANO ${ }^{224}$, M. TRIGGIANI ${ }^{225}$, S.I. TSARTARA ${ }^{71}$, A.L. VALERO ${ }^{226}$, E. VALOVIRTA $^{227}$, E. VAN GANSE ${ }^{228}$, M. VAN HAGE ${ }^{229}$, M. VAN DEN BERGE ${ }^{158}$, O. VANDENPLAS ${ }^{74}$, M.T. VENTURA $^{230}$, I. VERGARA ${ }^{231}$, G. VEZZANI ${ }^{232}$, D. VIDAL ${ }^{5}$, G. VIEGI $^{233}$, M. WAGEMANN $^{234}$, B. WHALLEY ${ }^{149}$, M. WICKMAN ${ }^{77}$, N. WILSON ${ }^{235}$, P.K. YIALLOUROS ${ }^{236}$, M. ŽAGAR ${ }^{159}$, A. ZAIDI $^{237}$, M. ZIDARN ${ }^{238}$, E.J. HOOGERWERF ${ }^{239}$, J. USERO ${ }^{239}$, R. ZUFFADA ${ }^{239}$, A. SENN ${ }^{240}$, B. DE OLIVEIRA-ALVES ${ }^{240}$

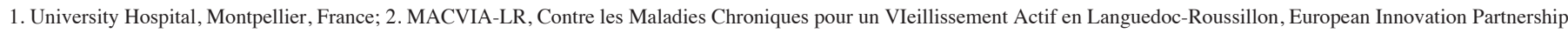
on Active and Healthy Ageing Reference Site, France; 3. INSERM, VIMA : Ageing and chronic diseases Epidemiological and public health approaches, U1168, Paris, and UVSQ, UMR-S 1168, Université Versailles St-Quentin-en-Yvelines, France; 4. iQ4U Consultants Ltd, London, UK; 5. Department of Pediatrics, Obstetrics and Gynecology, University of Valencia, Spain; 6. Computing Science Department, Umeå University, Sweden and Four Computing Oy, Finland; 7. Universidad Politécnica de Madrid (Life Supporting Technologies Research Group), Spain; 8. Medical University of Graz, Austria; 9. Integrated care \& technology, University Medical Center Utrecht, The Netherlands; 10. EIP on AHA, European Innovation Partnership on Active and Healthy Ageing, Reference Site, Scottish Centre for Telehealth and Telecare, NHS 24, Glasgow, UK; 11. TNO, Delft,The Netherlands;

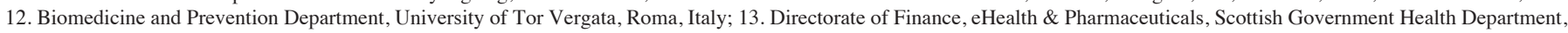

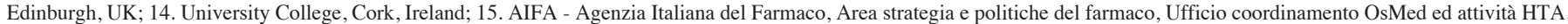
Roma, Italy; 16. Polibienestar Research Institute - University of Valencia, Spain; 17. University of Lower Silesia, Wrocław, Poland; 18. Division of Applied Technologies, National

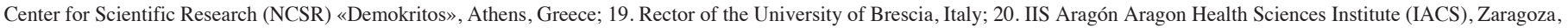
Spain; 21. European Health Futures Forum (EHFF), isle of Wright, UK; 22. Avisco, Capelle a/d Ijssel, The Netherlands; 23. Department of Health, Social Services and Public Safety , Northern Ireland Belfast, UK; 24. Institute of Biomedical Imaging and Life Sciences (IBILI), Faculty of Medicine, University of Coimbra, Portugal; Ageing@ Coimbra EIP-AHA Reference Site, Portugal; 25. Odense University Hospital, Region of Southern Denmark; 26. Assitant Director General, Montpellier, Région Languedoc Roussillon-Midi-Pyrénées,

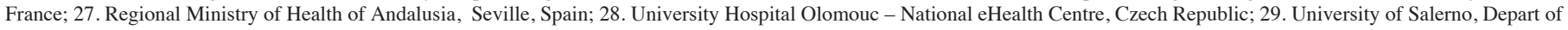

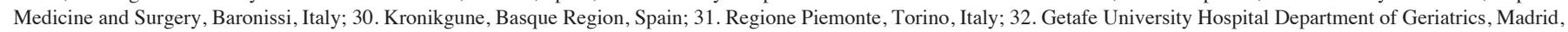

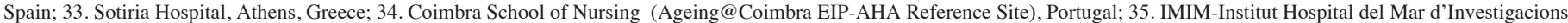
Mèdiques; 36. Regionie Puglia, Bari, Italy; 37. Department of Prevention of Environmental Hazards and Allergology, Medical University of Warsaw, Poland; 38. Department of

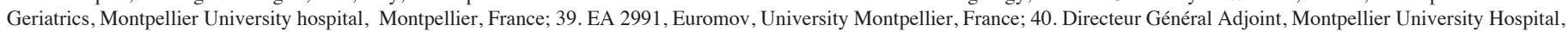
France; 41. Universidad Politecnica de Madrid (Life Supporting Technologies), Spain; 42. Technical University of Catalonia, Barcelona, Spain; 43 . Gérontopôle de Toulouse, 31059

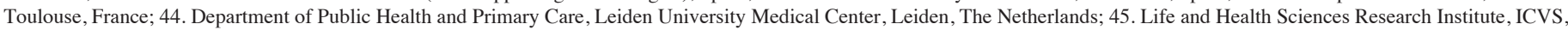

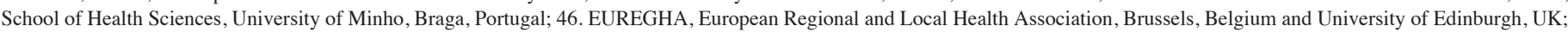
47. University of Valencia, Spain; 48. Department of Otorhinolaryngology, Academic Medical Centre, Amsterdam, Netherlands; 49. Institute of Health Carlos III (HTA Agency), Madrid, Spain; 50. CHRU Nice, France; 51. Laboratory of Clinical Immunology, Department of Microbiology and Immunology, KU Leuven, Leuven, Belgium; 52. Skin and Allergy

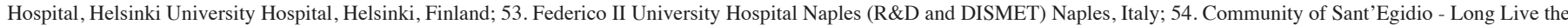
Elderly program; 55. Oslo University Hospital, Department of Paediatrics, Oslo, and University of Oslo, Faculty of Medicine, Institute of Clinical Medicine, Oslo, Norway; 56. First

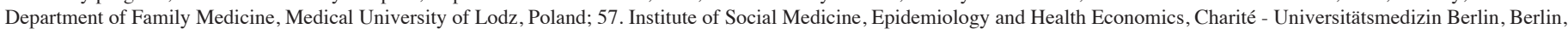
and Institute for Clinical Epidemiology and Biometry, University of Wuerzburg, Germany; 58. Internal and Geriatric Medicine, Department of Clinical and Experimental Medicine-

University of Parma, Prevention of Disability Lab Geriatric Clinic Unit University Hospital of Parma, Italy; 59. University of Deusto, Bilbao, Spain; 60. CIRFF, Center of

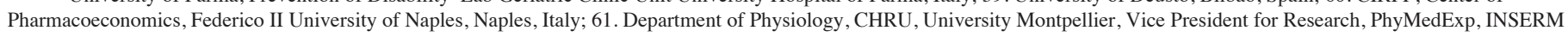
U1046, CNRS UMR 9214, France; 62. Past-President, European Union Geriatric Medicine Society and Editor, European Geriatric Medicine, Geneva, Switzerland; 63. NHS Scotland,

UK; 64. Caisse d'assurance retraite et de la santé au travail du Languedoc-Roussillon (CARSAT-LR), Montpellier, France; 65. AFFINITY, State Claims Agency/Health Service

Executive, Dublin, Ireland; 66. AGE Platform Europe, Brussels, Belgium; 67. Centre of Pneumology, Coimbra University Hospital, Portugal; 68. Department of Prevention of Envinronmental Hazards and Allergology, Medical University of Warsaw, Poland; 69. Institute for Microelectronics and Microsystems (IMM-CNR) and INNOVAAL (Public-Private Partnership on Active\& Healthy Ageing), Lecce, Italy; 70. Faculty of Sport Sciences and Physical Education, University of Coimbra (Ageing@Coimbra EIP-AHA Reference Site), Portugal, Portugal; 71. South East Europe Healthcare/ Integrated Care and Senior Tourism, Greece; 72. Vilnius University Public Health Institute, Center of Quality of Life Research, Vilnius University Clinic of Children's Diseases, Vilnius, Lithuania and European Academy of Paediatrics (EAP/UEMS-SP); 73. European Association of Pediatrics; 74. Dept of Chest Medicine, Centre Hospitalier Universitaire Dinant-Godinne, Université Catholique de Louvain, Yvoir, Belgium; 75. FILHA, Finnish Lung Association; 76. Roessingh Research and Development, Telemedicine group, Enschede, and University of Twente, Faculty of Electrical Engineering, Mathematics and Computer Science, Telemedicine group, Enschede, The

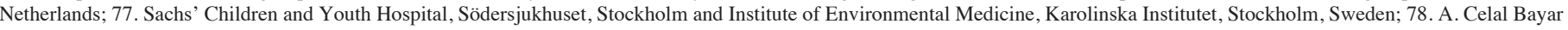

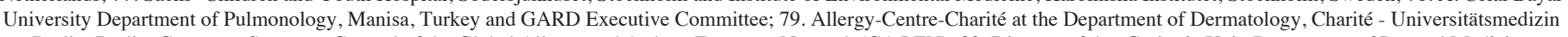
Berlin, Berlin, Germany; Secretary General of the Global Allergy and Asthma European Network (GA2LEN); 80. Director of the Geriatric Unit, Department of Internal Medicine

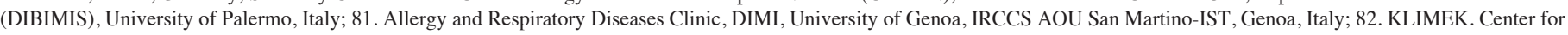
Rhinology and Allergology, Wiesbaden, Germany; 83. Research Director, CNR Aging Branch, Institute of Neuroscience, Padova, Italy; 84. Department of Dermatology, Medical

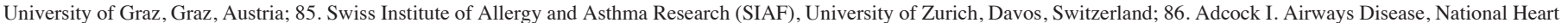
\& Lung Institute, Imperial College London, UK \& Biomedical Research Unit, Royal Brompton \& Harefield NHS Trust, London, UK; 87. Transylvania University Brasov, Brasov, Romania; 88. Chest Clinic, Turin University, Italy; 89. Andalusian Agency for Social Services and Dependency, Seville, Spain; 90. EPAR U707 INSERM, Paris and EPAR UMR-S UPMC, Paris VI, Paris, France; 91. David Hide Asthma and Allergy Research Centre, Isle of Wight, United Kingdom; 92. Aviitam, Montpellier, France; 93. Department of Endocrinology, Montpellier University Hospital, France; 94. Upper Airways Research Laboratory, ENT Dept, Ghent University Hospital, Ghent, Belgium; 95. Telbios, Milan, Italy; 96. Department of Respiratory Medicine, Academic Medical Center (AMC), University of Amsterdam, The Netherlands; 97. Centre for Individualized Medicine, Department of Pediatrics, Faculty off Medicine, LInköping University, Sweden; 98. Phillips Research Institute; 99. Department of Pathophysiology and Transplantation, University of Milan, IRCCS

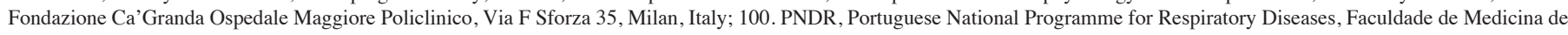
Lisboa, Lisbon, Portugal; 101. Second University of Naples and Institute of Translational Medicine, Italian National Research Council; 102. Institute of Lung Health, Respiratory Biomedical Unit, University Hospitals of Leicester NHS Trust, Leicestershire, UK; Department of Infection, Immunity and Inflammation, University of Leicester, Leicester, UK; 103. University of Medicine and Pharmacy Victor Babes, Timisoara, Romania; 104. Bush A. Imperial College and Royal Brompton Hospital, London, UK; 105. Department of Respiratory Diseases, Montpellier University Hospital, France; 106. Imperial College London - National Heart and Lung Institute, Royal Brompton Hospital NHS, London, UK;

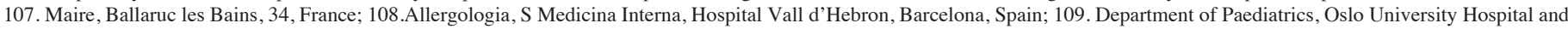

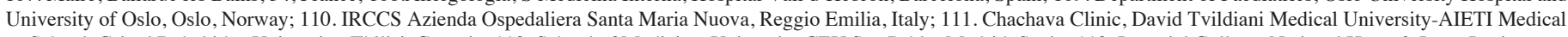
School, Grigol Robakidze University, Tbilisi, Georgia; 112. School of Medicine, University CEU San Pablo, Madrid, Spain; 113. Imperial College, National Heart \& Lung Institute, 


\section{SYNERGIES IN ACTIVE AND HEALTHY AGEING}

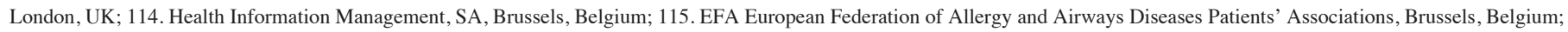

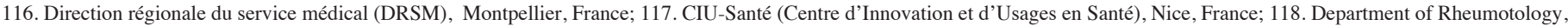
Universityhospital, Montpellier, France; 119. Conseil départemental de l'Hérault, Montpellier, France; 120. UCIBIO, Department of Biological Sciences, Faculty of Pharmacy, University of Porto, Porto, Portugal; 121. Directions régionales de la jeunesse, des sports et de la cohésion sociale (DRJSCS), Montpellier, France; 122. National Research Council,

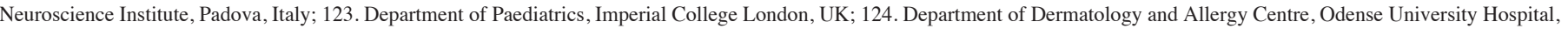
Odense, Denmark; 125. The Centre for Allergy Research, The Institute of Environmental Medicine, Karolinska Institutet, Stockholm, Sweden; 126. Laboratoire de Pharmacologie Respiratoire UPRES EA220, Hôpital Foch, Suresnes Université Versailles Saint-Quentin; 127. Rangueil-Larrey Hospital, Respiratory Diseases Department , Toulouse, France;

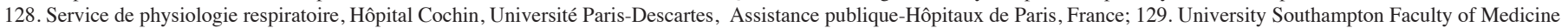

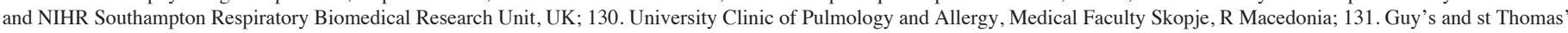

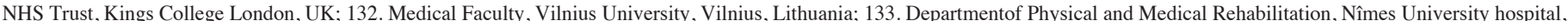

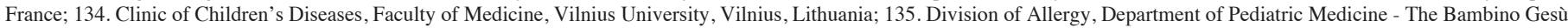

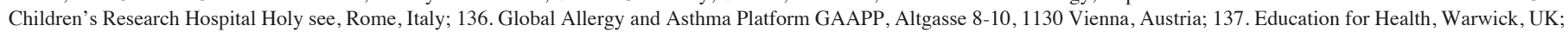
138. Center for research in health technologies and information systems- CINTESIS, Allergy Unit, Instituto CUF Porto e Hospital CUF Porto, Porto, Portugal ; Health Information and Decision Sciences Department - CIDES, Faculdade de Medicina, Universidade do Porto, Portugal; 139. National Center for Disease Control and Public Health of Georgia, Tbilisi,

Georgia; 140. ISGLoBAL, Centre for Research in Environmental Epidemiology (CREAL), IMIM (Hospital del Mar Research Institute), CIBER Epidemiología y Salud Pública (CIBERESP), Barcelona, Spain; 141. University of Deusto, Bilbao, Spain; 142. Department of Pulmonary Diseases, Istanbul University, Cerrahpasa Faculty of Medicine, Turkey;

143. Resident Medical Specialist on Medicine Mater Dei Hospital, La Valette, Malta; 144. Department of Respiratory Diseases, Odense University Hospital, Denmark; 145. Investén-

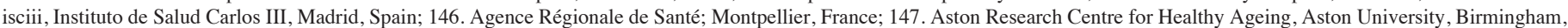

UK; 148. Université Paris-Sud; Service de Pneumologie, Hôpital Bicêtre; Inserm UMR_S999, Le Kremlin Bicêtre, Franc; 149. School of Psychology, Plymouth University, Plymouth,

UK; 150. Airway Disease Infection Section, National Heart and Lung Institute, Imperial College; MRC \& Asthma UK Centre in Allergic Mechanisms of Asthma, London, UK;

151. Allergology department, Centre de l'Asthme et des Allergies Hôpital d'Enfants Armand-Trousseau (APHP); Sorbonne Universités, UPMC Univ Paris 06, UMR_S 1136, Institut

Pierre Louis d'Epidémiologie et de Santé Publique, Equipe EPAR, F-75013, Paris, France; 152. Department of Clinical Immunology, Wrocław Medical University, Poland; 153.

Ukrainina Medical Stomatological Academy, Poltava, Ukraine; 154. National Research Center, Institute of Immunology, Federal Medicobiological Agency, Laboratory of Molecular immunology, Moscow, Russian Federation; 155. Pediatric Allergy and Asthma Unit, Hacettepe University School of Medicine, Ankara, Turkey; 156. Hacettepe University, School of Medicine, Department of Chest Diseases, Immunology and Allergy Division, Ankara, Turkey; 157. University Twente, Twente, the Netherlands and Health Information Management

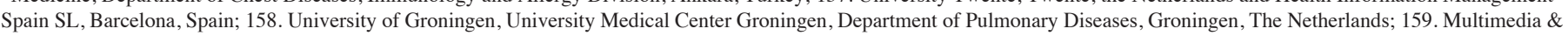

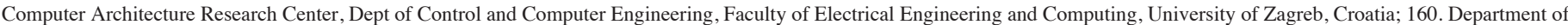
Immunology, Rheumatology and Allergy, Medical University of Lodz, and HARC, Poland; 161. University of Groningen, University Medical Center Groningen, Beatrix Children's Hospital, Department of Pediatric Pulmonology and Pediatric Allergology, GRIACResearch Institute, Groningen, the Netherlands; 162. Department of Geriatrics, Healthy Ageing Research Centre, Medical University of Lodz, Poland; 163. Division of Internal Medicine, Asthma and Allergy, Barlicki University Hospital, Medical University of Lodz, Poland;

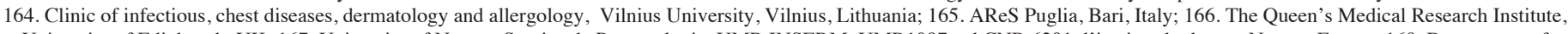
University of Edinburgh, UK; 167. University of Nantes, Service de Pneumologie, UMR INSERM, UMR1087and CNR 6291, 1'institut du thorax, Nantes, France; 168. Department of

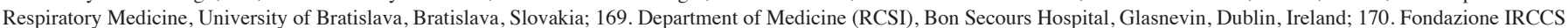

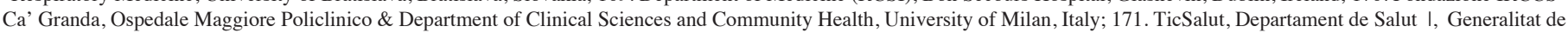

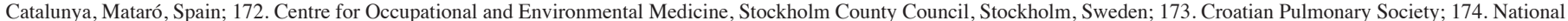

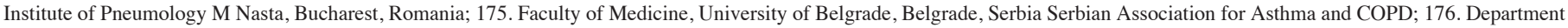
of Public health and health products, Paris Descartes University-Sorbonne Paris Cité, EA 4064 and Paris municipal Department of social action, childhood, and health, Paris, France;

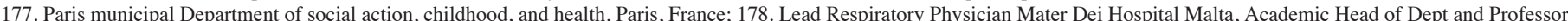

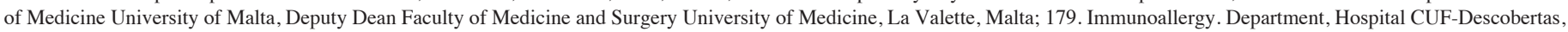
Lisbon, Portugal; 180. Sociedade Portuguesa de Alergologia e Imunologia Clínica; 181. Institute of Health Carlos III (Nursing and Health Care Research Unit), Madrid, Spain;

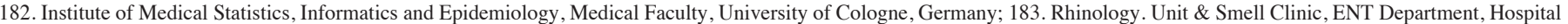

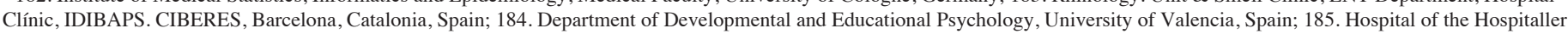

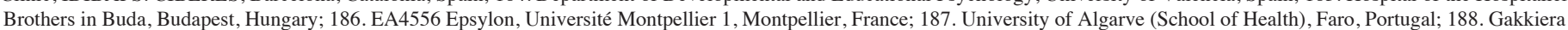
Hospital Department of Geriatrics, Genoa, Italy; 189. Department of Immunology and Allergology, Faculty of Medicine and Faculty Hospital in Pilsen, Charles University in Prague,

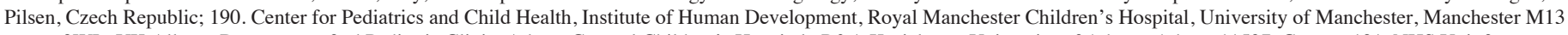

9WL, UK Allergy Department, 2nd Pediatric Clinic, Athens General Children's Hospital «P\&A Kyriakou,» University of Athens, Athens 11527, Greece; 191. NHS Unit for Hemoglobinopathies prevention and treatment, Laikon general Hospital Athens, Greece; 192. L'ETAPE - Pôle Autonomie Santé, CCAS de Lattes, 34 970 Lattes, France; 193. Conseil régional de l'Ordre des Masseurs Kinésithérapeutes, Maison des Professions Libérales, 34000 Montpellier, France; 194. Régime social des indépendants (RSI), Montpellier, France;

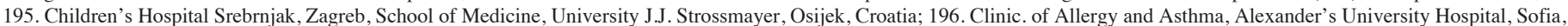
Bulgaria; 197. University of Groningen, University Medical Center Groningen, Department of Pulmonary Medicine and Tuberculosis, GRIAC Research institute, Groningen, the Netherlands; 198. Optimum Patient Care, Cambridge and Academic Centre of Primary Care, University of Aberdeen, Aberdeen, UK; 199. Société Publique Locale d'Exploitation de

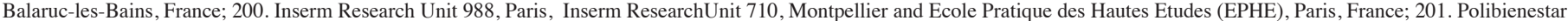

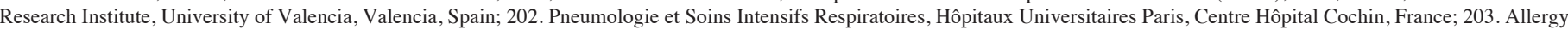

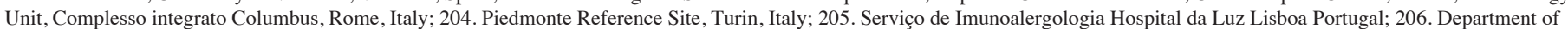
Cardiology, Montpellier University Hospital, France; 207. General Practitioner, Woodbrook Medical Centre, Loughborough, UK; Honorary Clinical Research Fellow, Allergy and Respiratory Research Group, The University of Edinburgh, Edinburgh, UK; 208. ITACA - Universitat Politècnica de Valéncia, Spain; 209. Allergy Unit, Department of Dermatology, University Hospital of Zurich, Zürich, Switzerland; 210. Helmholtz Zentrum München/Institute of Epidemiology I. Germany; 211. Cochrane Germany, Medical Center, University of Freiburg, Germany; 212. Otolaryngology and Head \& Neck Surgery, CHU Rangueil-Larrey, Toulouse, France; 213. Allergy and Respiratory Research Group, Centre for Population Health Sciences, The University of Edinburgh, Medical Schoo; 214. Child. Health, Queen's University Belfast \& Royal Belfast Hospital for Sick Children, UK; 215. Department of Thoracic Medicine, University Hospital of Heraklion, Crete, Greece; 216. DIBIMIS, University of Palermo, Italy; 217. Department of Otorhinolaryngology, Akershun University

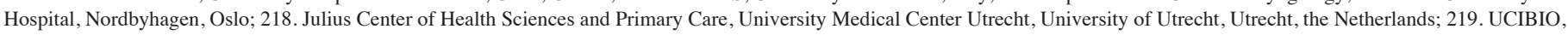
Faculty of Pharmacy, University of Porto, Portugal; 220. Kyrgyzstan National Centre of Cardiology and Internal medicine, Euro-Asian respiratory Society, Bishkek, Kyrgyzstan;

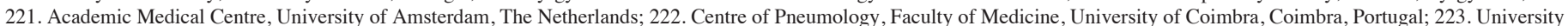
Hospital Montpellier, France; 224. University Federico II of Naples, Dpt of Molecular Medicine and Medical Biotecnology; GENS Foundation, Italy; 225. Division of Allergy and

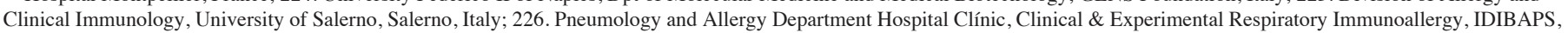

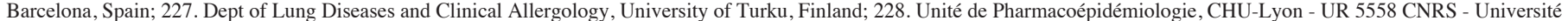

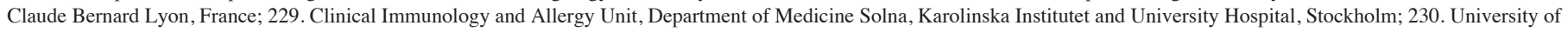

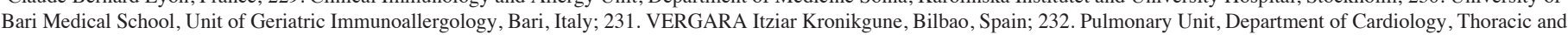
Vascular Medicine, Arcispedale SMaria Nuova/IRCCS, Research Hospital, Reggio Emilia, Italy, Regional Agency for Health and Social Care; 233. CNR, Pisa, Italy; 234. Dept of Otorhinolaryngology, HNO-Klinik, Universitätsklinikum Düsseldorf, Germany; 235. North of England EU Health Partnership, Newcastle, UK; 236. Cyprus International Institute for

Environmental \& Public Health in Association with Harvard School of Public Health, Cyprus University of Technology, Limassol, Cyprus; Department of Pediatrics, Hospital

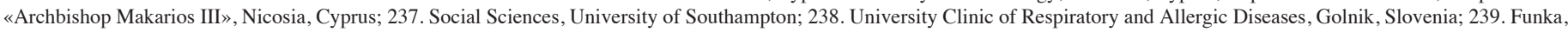

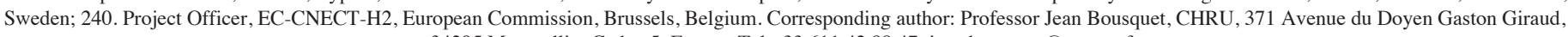
34295 Montpellier Cedex 5, France, Tel +33 6114288 47, jean.bousquet@orange.fr 


\title{
JNHA: GERIATRIC SCIENCE
}

\begin{abstract}
The Strategic Implementation Plan of the European Innovation Partnership on Active and Healthy Ageing (EIP on AHA) proposed six Action Groups. After almost three years of activity, many achievements have been obtained through commitments or collaborative work of the Action Groups. However, they have often worked in silos and, consequently, synergies between Action Groups have been proposed to strengthen the triple win of the EIP on AHA. The paper presents the methodology and current status of the Task Force on EIP on AHA synergies. Synergies are in line with the Action Groups' new Renovated Action Plan (2016-2018) to ensure that their future objectives are coherent and fully connected. The outcomes and impact of synergies are using the Monitoring and Assessment Framework for the EIP on AHA (MAFEIP). Eight proposals for synergies have been approved by the Task Force: Five cross-cutting synergies which can be used for all current and future synergies as they consider overarching domains (appropriate polypharmacy, citizen empowerment, teaching and coaching on AHA, deployment of synergies to EU regions, Responsible Research and Innovation), and three cross-cutting synergies focussing on current Action Group activities (falls, frailty, integrated care and chronic respiratory diseases).
\end{abstract}

Key words: European Innovation Partnership on Active and Healthy Ageing, polypharmacy, education, falls, frailty, integrated care, citizen empowerment, chronic respiratory diseases.

Abbreviations: AG: Action Group; AHA: Active and Healthy Ageing; CoP: Conference of Partners; CRD: Chronic Respiratory Diseases; EICA: European Interdisciplinary Council on Ageing; EIP on AHA: European Innovation Partnership on Active and Healthy Ageing; EU: European Union; ICT: Information and Communication Technology; MACVIA-LR: Reference Site Contre les MAladies Chroniques pour un VIeillissement Actif en Languedoc-Roussillon; MAFEIP: Monitoring and Assessment Framework for the EIP on AHA; PROEIPAHA: Support Action to the EIP on AHA; QALY: Quality-Adjusted-Life-Years; QOL: Quality of life; RAP: Renovated Action Plan; RRI: Responsible Research and Innovation; RSCN: Reference Site Collaborative Network; TF: Task Force; WHO: World Health Organization; WHODAS 2.0: World Health Organization Disability Assessment Schedule 2.0

\section{Introduction}

The European Commission aims to enhance European competitiveness and tackle societal challenges through research and innovation (European Innovation Partnerships (EIP). Active and Healthy Ageing (AHA) is a major health and societal challenge in all European countries, and an area with considerable potential for European leadership. An initiative was therefore launched by the EIP on AHA to accomplish a triple win (1):

- Enabling citizens to lead healthy, active and independent lives while ageing.

- Improving the sustainability and efficiency of social and health care systems.

- Boosting and improving the competitiveness of the markets for innovative products and services responding to the ageing challenge.

The EIP on AHA programme framework defined priority areas of work translated into six specific Action Groups (AG). Over 500 commitments were submitted from organisations (Table 1) and 32 Reference Sites were recognised in July 2013 as excellence sites for innovation in AHA.

\section{Aim of the Task Force on synergies}

The EIP on AHA requires a multidimensional and multidisciplinary approach. After three years of collaboration and activities, many achievements have been obtained. However, AGs have often worked in silos. Now that AGs have

Table 1

Terminology used in the paper

Organisations can participate in the EIP on AHA using:

- Individual commitments: Individual task of an AG.

- Collaborative work: Project agreed by an AG and carried out by several organisations.

Results are tangible outcomes from commitments and/or collaborative work (e.g. a report, a completed pilot study, a guideline, etc.). They have to be specific, measurable, achievable and time-bound.

Synergies (defined by the Synergy TF in coordination with AGs): Commitments and/or collaborative work with cross-cutting interest and relevance to several AGs. They were established using a concerted approach. A synergy should be in line with the individual AG's Renovated Action Plan.

Collaborative work and Synergies can be managed on a voluntary basis following the objectives set or in a more agile way using SPRINTS that are proposed using a specific template with defined short-term results reported every 6 months. In software product development, a sprint is a set period of time during which specific work has to be completed (http://searchsoftwarequality.techtarget.com/definition/Scrum-sprint). 


\section{SYNERGIES IN ACTIVE AND HEALTHY AGEING}

matured, more attention can be given to collaboration across AGs for topics with a shared interest.

In the next phase of the EIP on AHA programme, synergies will be initiated for a practical, action-oriented contribution to a common framework to further strengthen the EIP on AHA triple win.

More specifically, the aims of the TF are to:

1- Outline the methodology and current status of the EIP on AHA synergies.

2- Align with the AG Renovated Action Plan (RAP).

3- Evaluate the progress, results and impacts of the synergies with MAFEIP (Monitoring and Assessment Framework for the EIP on AHA) $(2,3)$.

4- Support the existing EIP on AHA Scaling Up Strategy (https://ec.europa.eu/research/innovation-union/pdf/activehealthy-ageing/scaling_up_strategy.pdf)

\section{Methodology used by the Task Force to develop synergies}

\section{Selection of task force members}

A TF was set up to identify synergies, and to describe and evaluate them. Initially, each AG selected at least 2 members. Members of the PROEIPAHA Coordination and Support Action and the AG promoters were also invited to participate in the TF.

\section{Template to develop proposals for synergies}

Synergies were based on a common 4-page template that was unanimously agreed upon by all the TF members (Table 2).

\section{Assessment of proposals}

A transparent methodology was developed to evaluate the synergies on relevance, quality and applicability. The templates were evaluated by two members from each AG based on a set of criteria checked through Survey Monkey (Figure 1) (www. surveymonkey.com). All proposals with a threshold mean level of $6 / 10$ or above for all the 9 criteria were approved (a unanimous decision was required). The inter-rater variance was low between assessments. Proposals that did not reach the threshold level were revised and further approved. Finally, 8 proposals were accepted and one was withdrawn.

Figure 1

Survey Monkey evaluation of proposed synergies

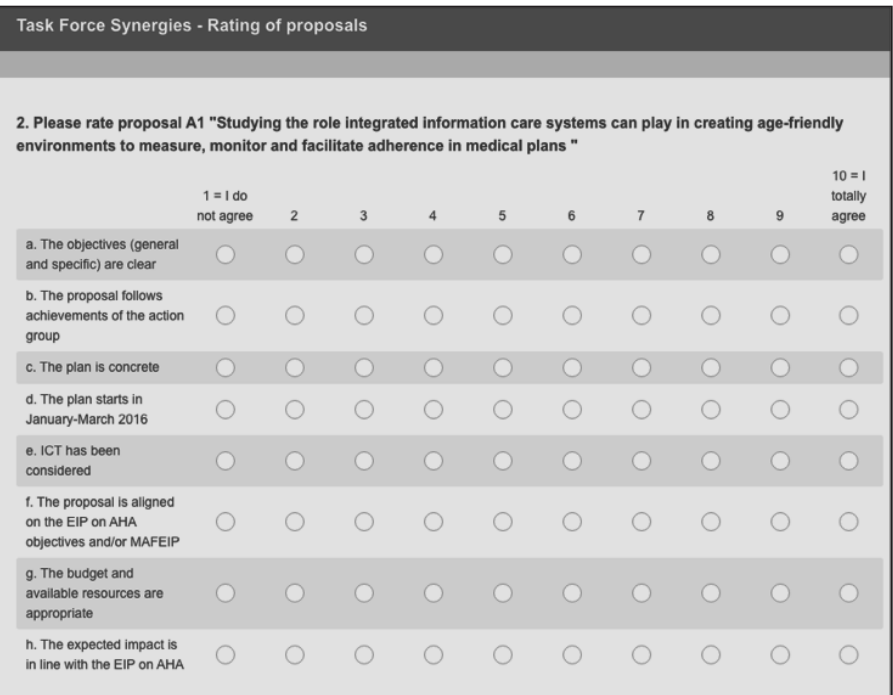

Table 2

Template used to submit synergies

1. Title of the proposal

2. Leading organisation

3. Supporting organisations

4. Action groups

AG initiating the proposal

AG already involved

AG to be contacted

5. Rationale for the synergy

6. Achievements of the EIP on AHA AG

7. Objectives

- General objectives

- Specific objectives

8. Concrete plan

9. SPRINTS (2016-2017)

$N^{\circ} \quad$ Name

Name

$\mathrm{S} 1$

Starting date

Delivery date

Geographical distribution

Results

10. Associated EU programmes

11. Alignment with the EIP on AHA objectives

12. Resources currently available for the projects

13. Expected impact 


\section{JNHA: GERIATRIC SCIENCE}

\section{Type of synergies}

Two types of complementary cross-cutting synergies were submitted (Figure 2):

- Synergies considered overarching as they address topics that are relevant for most or all AGs

- Cross-cutting synergies focussing on a current AG activity which will be deployed to other AGs

The 8 synergies are detailed in the online supplement.

Figure 2

Synergies of the EIP on AHA

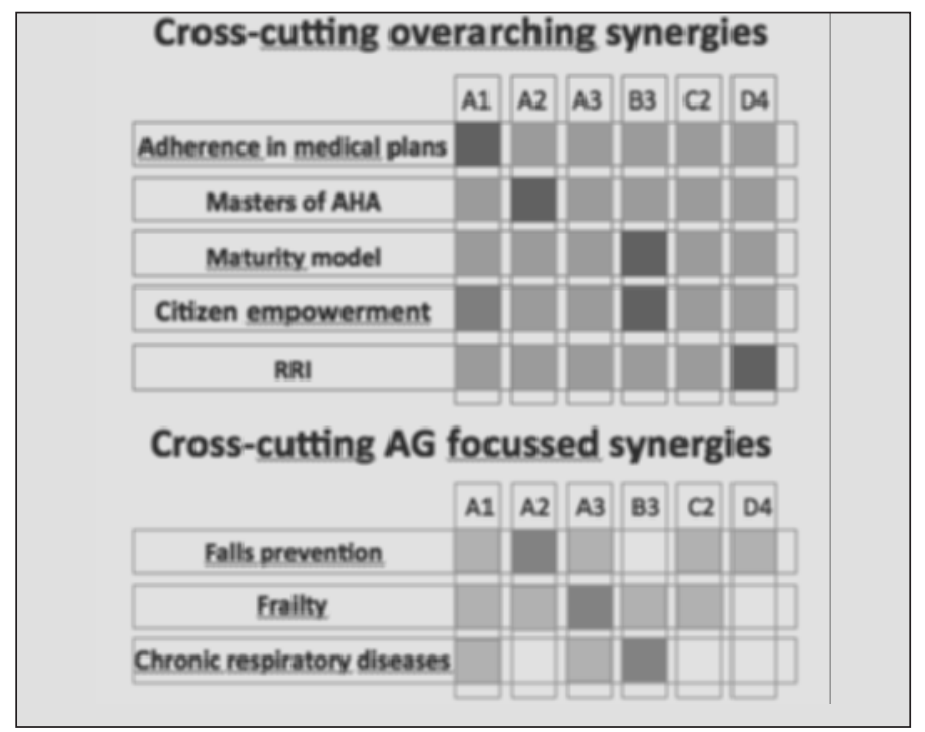

Activities of the Proposed Synergies

\section{Overarching synergies}

Information technology and adherence in an ageing population with chronic diseases and appropriate polypharmacy

Leading AG: A1

Rationale: Multimorbidity leads to multiple medications (polypharmacy), increasing the risk of drug interactions, poor treatment adherence and adverse drug reactions (ADR). Failure to adhere to medical treatment increases therapeutic failure (5), causes unnecessary complications (6) and increases hospitalization and healthcare costs (7).

General objectives: To increase the adherence to treatment of seniors with chronic diseases and polypharmacy (i) assessing the role of ICT-based solutions and (ii) implementing tailored ICT- based interventions.

Specific objectives

1- To study if the application of progressive ICT systems that connect patients with health care professionals can boost the adherence of seniors in long-term therapies and polypharmacy, also considering pharmacists. Results from running pilots in the EU will be used for deployment.

2- To study the role of integrated information systems connecting all stakeholders (e.g. patients, family members, health and social carers, and members of municipalities, hospitals, social care entities). Results from a running pilot in the EU will be used for deployment.

3- To review best practices and available literature to assess whether ICT-based applications that support training, patient empowerment and social interactions can change the behaviour and increase the adherence of seniors to treatment.

4- To use the lessons learnt in Italy by a National plan for Adherence involving the Italian Medicines Agency (AIFA), the national federation of general practitionners (FIMMG), Geriatrics and Patients associations (in particular Federanziani) and universities. The barriers and results of this network can be used to develop or scale up innovative approaches at the EU level.

Contribution to the Scaling Up Strategy of the EIP on AHA: The study intends to exploit results from many EU countries.

Expected Outcomes / Contribution to MAFEIP

1- Impact on QOL: Increased adherence of seniors to medical plans will promote healthier ageing and QOL while reducing complications.

2- Increased adherence to medical plans will impact the sustainability of the healthcare systems. Specific metrics used in the study are currently being defined.

3-Impact on Economic, Growth and Jobs for both the pharmaceutical industry and in the area of home care technologies and services. Opportunities for the development and production of new advanced products are expected to be generated leading to the requirement of more qualified jobs for the new services.

\section{Citizen and patient empowerment}

Leading AG: B3, Action Area 6

Rationale: Nearly all the Action Plans launched in 2012 refer to patient or citizen empowerment. An active involvement of patients in their interaction with health and social professionals increases care effectiveness and efficiency. Citizen empowerment and the facilitating role of ICT are key topics in the EU H2020 programme. However, the work done in the EIP on AHA has shown divergent understanding of citizen empowerment, defined in terms of education, joint decisionmaking and self-management. Tools such as measures of health literacy and the capacity of individuals or groups for selfmanagement in chronic conditions would be of considerable value in reducing social inequalities.

General objectives: To achieve a common understanding of citizen and patient empowerment, and to implement and scaleup good practices.

Specific objectives

1- Develop a consensus view of citizen and patient empowerment across the different AGs. 
2- Share and align citizen empowerment-related activities within and across AGs.

3- Formulate a set of broad holistic actions, based on a common understanding, to facilitate the scaling-up of good and effective practices via transverse (Synergies TF) as well as vertical processes (AGs) that support the overall objectives of the EIP on AHA.

4- Scale-up good practices and disseminate knowledge via the Synergies TF, the AGs, the Reference Sites and relevant EU and national initiatives.

Contribution to the Scaling Up Strategy of the EIP on AHA: How many regions?

All EIP on AHA partners and regions will be involved in this synergy. Additionally, all Reference Sites in the Reference Site Collaborative Network (RSCN) will be invited to participate.

Expected Outcomes / Contribution to MAFEIP: "Patients with chronic conditions are often referred to as the most underused resource in the health system while patient-centred care models have demonstrated better quality of care as well as potential long-term cost-efficiencies. Too many patients are still struggling to get the support they need to become equal partners in care. To make real progress, we need to make patient empowerment a priority, starting with the development of an EU-wide strategy and action plan"

1. Impact on QOL with an adequate social network and sufficient empowerment (8-11).

2. Empowerment of patients and citizens is seen as a key aspect in maintaining health and care systems sustainable $(12,13)$.

3. Empowered citizens are more self-sustaining and economically productive $(14,15)$.
Masters of AHA educating seniors, health and social carers and entrepreneurs

Leading AG: A2

Rationale: Integrated, interdisciplinary and inter-professional education for all stakeholders is needed to tackle the interrelated syndrome of frailty, malnutrition, falls, chronic diseases, and their social consequences.

General objectives: Development of an innovative, dynamic and sustainable care system for AHA by capacity building through senior/patient-centred, multidisciplinary and interprofessional educational programmes aimed at patients, patient caregivers (both formal and informal), health and social carers, administrators and entrepreneurs.

Specific objectives:

1- Multi-professional education to improve the links between all stakeholders through better understanding of the knowledge and competencies of each stakeholder.

2- Master of Gerontology and Geriatrics: To develop dynamic and sustainable care systems that will encompass interdisciplinary, inter-professional education (IPE) and learning (IPL) including RRI business models.

3- Best evidence holistic perspective to bring together research, practice, policies and market by courses in medical, nursing, pharmacy, social, behavioural, psychological, economic physiological, management service aspects related to the prevention and management of ageing and using the innovation loop of planning up-scaling strategies.

4- To promote AHA as well as the empowerment of self-care and (care) independency, by placing the older person at the centre of care.

Table 3

Examples of Masters of Gerontology and Geriatrics in Europe

\begin{tabular}{|c|c|c|c|c|}
\hline Country & Region or Reference site & Website & Title & Language \\
\hline Austria & Graz Medical University & & $\begin{array}{l}\text { Master of Gerontology and Geria- } \\
\text { trics }\end{array}$ & English \\
\hline Austria & $\begin{array}{l}\text { Medical Doctors' Associa- } \\
\text { tion Austria }\end{array}$ & $\begin{array}{l}\text { http://www.aerztekammer. } \\
\text { at/veranstaltungen }\end{array}$ & $\begin{array}{l}\text { Postgraduate Training Course for } \\
\text { Medical Doctors in Geriatric Medi- } \\
\text { cine }\end{array}$ & German \\
\hline Belgium & $\begin{array}{l}\text { European Academy of } \\
\text { Aging (EAMA) }\end{array}$ & http://eama.eu & $\begin{array}{l}\text { Leadership programme for academic } \\
\text { geriatricians }\end{array}$ & English \\
\hline France & $\begin{array}{l}\text { Languedoc Roussillon } \\
(16-18)\end{array}$ & $\begin{array}{l}\text { http://reseau-idefi- } 2015 . \\
\text { strikingly.com }\end{array}$ & $\begin{array}{l}\text { Trans Innov Longévité: Trans-disci- } \\
\text { plinary, multisectoral, private-public } \\
\text { partnership to train and coach on } \\
\text { frailty, ageing and independent living }\end{array}$ & French \\
\hline Portugal & Ageing@Coimbra & $\begin{array}{l}\text { http://www.ed.uc.pt/educ/ } \\
\text { cursoid=96 }\end{array}$ & $\begin{array}{l}\text { Distance Learning Course for Care } \\
\text { Providers and the general public }\end{array}$ & Portuguese \\
\hline UK & British Geriatric Society & http://www.bgs.org & $\begin{array}{l}\text { Spring Postgraduate training course, } \\
\text { geriatric medicine, Edinburgh } \\
\text { Scotland }\end{array}$ & English \\
\hline UK & University of Oxford & http://www.oxford.edu. & Onsite training courses & English \\
\hline
\end{tabular}




\section{JNHA: GERIATRIC SCIENCE}

Contribution to the Scaling Up Strategy of the EIP on AHA: The programme will be started at the Medical University of Graz, Austria by a well-defined Master of Gerontology and Geriatrics. The course will be in English and the teachers and participants will be from different institutions in Europe. This programme will be a pilot for other European programmes. The multi-professional approach will be developed in collaboration with the European Interdisciplinary Council on Ageing (EICA) gathering professionals from all disciplines interested in AHA and also implementing knowledge transfer to political, economic and lay stakeholders in the field.

Regions to be included: Regions will have a role for contributors, sharing their experiences and best practices, as well as for learners. Some examples of education programmes carried out in other regions are given in Table 3.

Efficient running of the programme: A scientific advisory committee is elaborating a landscape of educational events (homepage of the Medical University of Graz/Austria). Experts in the field of AHA will set up quality standards for live or long-distance educational events in the field of AHA (e-learning). The committee is composed of members from all stakeholders involved in AHA across Europe. The committee will work closely with the members of the RRI framework to ensure evidence-based multi-professional education and to deliver educational research results.

Expected Outcomes / Contribution to MAFEIP

1- Impact on the QOL of seniors

2- Ensure health promotion, literacy, engagement and empowerment of senior citizens in aspects related to adopting interventions and life styles that promote active and health ageing (e.g. acceptance of evidence-based interventions, behavioural changes towards AHA).

3- Impact on the Sustainability of Health and Care Systems

4- Impact on Economic, Growth and Jobs

\section{AHA in the framework of Responsible Research and} Innovation (RRI)

Leading AG: D4

Rationale: Responsible Research and Innovation (RRI) is an approach anticipating and assessing potential implications and societal expectations of research and innovation $(19,20)$. RRI allows all stakeholders involved in research and innovation (i) to obtain relevant knowledge on the consequences of the outcomes of their actions, (ii) to effectively evaluate outcomes in terms of societal needs and moral values and (iii) to use these considerations for the design and development of new research, products and services (19). The concept in Europe considers eight key areas (21) that should be included in the dialogue among the different AGs of the EIP on AHA: Governance, Public Engagement, Gender Equality, Science Education, Open Science/Open access, Ethics, Sustainability and Social Justice/ Inclusion.

General objectives: To provide a roadmap of actions to be undertaken to promote RRI in AHA.
Specific objectives:

1- To identify the current state of the actions and initiatives related to the concept of RRI in the AHA framework and the concrete contribution of the partners and AGs.

2- To create a group of partners interested in working in this area and to identfy the most urgent actions and the plan of execution for RRI in AHA for the following years.

3- To analyse the work done in AHA in terms of RRI in the framework of the EIP on AHA and other related networks.

4- To provide a roadmap of urgent actions to be undertaken in RRI for AHA.

Contribution to the Scaling Up Strategy of the EIP on AHA: The synergy considers the engagement of higher numbers and more diverse stakeholders involved in the chain supply of active and healthy ageing products and services. These would include grass-root stakeholders (at local and regional level) with no possibility to join the EIP on AHA in Brussels due to economic, linguistic or time limitations and would enable the promotion of a richer dialogue and collaboration. The D4 partners/coordinators suggested the consideration of new agents as actors participating in AHA promotion at early stages and other actors supporting innovative ways of promoting active seniors i.e., schools, volunteers, touristic operators, social entrepreneurs.

Expected Outcomes / Contribution to MAFEIP: Integration of the concept of RRI to AHA is lacking. This synergy will create a baseline for future development and the integration of this trend in a structured and holistic way with the support of relevant stakeholders.

\section{Maturity Model for Integrated Care}

Leading AG: B3, Action Area 7

Rationale: Scaling up of EIP on AHA good practices in integrated care to EU regions is essential to reduce health, gender and social inequities in Europe.

General objectives: The B3 AG has developed the B3 Maturity Model to assist regions with their efforts to deploy integrated care in Europe in order (i) to reveal the strengths and weaknesses of European regions, (ii) to match those with similar problems and environments to work together and (iii) to help regions scale up their activities.

Specific objectives

1. To share learning and expertise gained during the development of the B3 Maturity Model

2. To adjust the Maturity Model to address challenges of ageing in Europe such as adherence, frailty, falls prevention and assisted living solutions.

3. To develop self-assessment tool(s) to assess the readiness of regions in the implementation of solutions for AHA.

4. To test and validate the Maturity Model as a tool for supporting the scaling up and replication of innovative solutions; and facilitating knowledge transfer and exchange of good practices in Europe. 


\section{SYNERGIES IN ACTIVE AND HEALTHY AGEING}

Contribution to the Scaling Up Strategy of the EIP on AHA: Aiming to conduct self-assessment in 8 regions, with twinning and coaching activities facilitated by B3 regions.

Expected Outcomes / Contribution to MAFEIP

1- Scaling up effective integrated care will improve the quality of care, health and wellbeing of citizens.

2- Positioning of European regions in terms of strengths and weaknesses will inform national, regional and local authorities about their "future direction of travel" - quick and systematic identification of areas that need attention to achieve improvement in AHA solutions.

3- Integration of health and care will lead to new roles and competencies for the workforce, and will generate opportunities for growth through scaling up of effective models of care / solutions.

\section{Cross-cutting synergies focussed on an Action Group}

\section{Falls prevention and injuries: a grand societal challenge}

Leading AG: A2

Rationale: Falls represent a major cause of burden and death in seniors (22). Approximately $30 \%$ of falls result in an injury that requires medical attention. Fractures occur in approximately 5\% of falls and hip fractures in 1\% (23-26). Falls-related injuries account for over $5 \%$ of the medical expenditures in seniors. Falls are the third leading cause of years lived with disability.

General objectives: To scale up a falls prevention and injuries initiative from local pilot studies to a practical and feasible pan-European programme including all stakeholders.

Specific objectives

1- Enable macro-, meso- and micro-level analysis including governance and policy-making based on screening, prevention, rehabilitation and monitoring, as well as an integration with the Silver Economy, and related to WHO's consultation on Global Strategy and Action Plan on Ageing and Health.

2- Engage regional and municipal levels in fall prevention campaigns, thereby enabling and promoting early frailty and fall risk assessment, and identifying frail and faller profiles.

3- Anticipate and identify the data analytic scope for health outcome studies in order to utilize the infrastructure and support the widest possible variety of health and social studies, including support for further methods and care service developments related to frailty and fall injury intervention and prevention.

4- Raise awareness and promote behavioural change among citizens in the prevention of frailty and fall injuries including post-operative interventions.

5- Understand falls-risk-increasing drugs and frailty.

6- Provision of specific smart home and smart building oriented ICT solutions viewed from a socio-economic Key Performance Index perspective.
Contribution to the Scaling Up Strategy of the EIP on AHA: How many regions?: Five to ten demonstrator regions are proposed, including Austria/Steiermark, Finland, France/ Languedoc-Roussillon, Ireland, Scotland, Spain (Region of Madrid-Getafe University Hospital and Basque country). Austria, Finland and France have agreed. Discussions are ongoing with others.

Expected Outcomes / Contribution to MAFEIP: Scalingup of good practices with an extended MAFEIP monitoring framework $(2,3)$ including socio-economic and macroeconomic aspects.

1- Fall risk assessment is often embedded into a broader scope of geriatric assessment, e.g. including cognitive and noncognitive aspects of dementia, activities of daily life (ADL), QOL, depression and nutrition. EQ5D is often used but is not sufficient for a broader scope of assessment. Finer granularity is needed.

2- Pathways and care processes are important ingredients in sustainability. This process of sustainability is discussed within the AG.

3- Impact on Growth and Jobs: The AG is discussing the whole ecosystem, from both topdown and bottom up approaches.

Impact of the Community-based Programme on Frailty Prevention and frailty Mitigation (ICP - FPM)

Leading AG: A3

Rationale: Prevention, screening, early identification and diagnosis of frailty and functional decline are closely related with the integrated care of chronic diseases. They operate primarily in the community, requiring the integration of health (primary, secondary) and social care to deliver screening, targeted assessment (e.g. Comprehensive Geriatric Assessment) and evidence-based, cost effective and tailored interventions (27-30). This comprehensive approach aims to prevent disability, recurrent hospitalizations, institutionalization and related heath-social care costs $(27,31,32)$. Interventions must integrate health care and a supportive social environment for the patient and caregiver $(33,34)$. Women may be at higher rates of physical and cognitive frailty and interventions must be gender and cultural sensitive.

General Objective:

To set up a public health approach

- To prevent, identify and manage frailty in community dwelling older adults, to be validated in different EU member states,

- To identify the factors that can be targeted in order to, delay or postpone further decline and disability.

Specific objectives

1. To join systematic frailty assessment with good practices in frailty prevention and management, by counteracting social isolation, and improving nutrition, adherence to therapy and physical activity.

2. To promote the continuum of care by integrating social and 


\section{JNHA: GERIATRIC SCIENCE}

health care at primary, secondary and tertiary levels.

3. To assess the impact of this public health model to manage frailty in the community in terms of cost effectiveness, use of health services, acceptance by citizens and patients' QOL.

4. To test the relation between a set of indicators and the prevalence of frailty.

5. To exploit existing ICT-supported assessment and intervention tools.

6. To describe the weaknesses and strengths of caregiver networks, and implement strategies to maintain, supplement and improve this network.

Contribution to the Scaling Up Strategy of the EIP on AHA: The proposal includes projects already developed in six European countries and is going to include organizations based in two more countries. The objective of the proposal is to represent all European Regions.

Expected Outcomes / Contribution to MAFEIP

1- Community-based programmes should reduce mortality, hospitalization and institutionalization rates in order to improve QOL in the elderly.

2- The proposal will assess the capacity of different interventions aimed to strengthen community-based health and social care programmes and reduce the work load on hospitals and residential Long Term Care services that are much more expensive.

3- Impact on Growth and Jobs: strengthening community-based services needs an increased number of dedicated personnel with potential benefit for the employment levels.

4- Some markers of the availability of socio-economic resources will also be assessed for their impact on frailty because of their strong relation with mortality rate and an increased use of health resources such as hospitalization and institutionalizations.

Multimorbidity of chronic respiratory diseases in seniors: an under-recognised societal problem (B3)

Leading AG: B3, Action Area 5

Rationale: Chronic Respiratory Diseases (CRD) are major chronic diseases. Some occur early in life (e.g. asthma-rhinitis) and persist throughout life $(35,36)$. COPD is associated with frailty in seniors (multimorbidity, polymedication). CRDs are intertwined with ageing and negatively impact AHA. The prevention and control of CRD in the ageing population is vital. Integrated care pathways have been set up for CRDs (AIRWAYS ICPs) in the B3 AG (37-39).

General objectives: To better understand, prevent, detect and manage CRDs in elderly people, and to assess the impact of their socio-economic and health services utilization. Simple ICT tools allowing individualised medication should be developed. To raise the awareness of the role of CRDs in the elderly, and advocate for a European strategy, in order to support the scaling up of regional interventions. A stepwise action plan is proposed including scientific societies and the involvement of patient's organisations.

Specific objectives

1- Promotion of AHA: Fit at work with rhinitis: Rhinitis impacts work productivity more than diabetes, hypertension or asthma. In Europe, work productivity costs due to rhinitis are over $30 \mathrm{~B} €$ yearly. The control of rhinitis by treatment improves work productivity (40). This project includes care pathways and should be a pilot for other common chronic diseases.

2- Ageing well with rare paediatric diseases (e.g. cystic fibrosis (CF) or bronchopulmonary dysplasia): The transition between paediatrics, adult medicine and geriatrics is a key issue for AHA in this severe genetic disease. The model of $\mathrm{CF}$ can be deployed to other rare diseases (41).

3- Understanding, promoting health and controlling CRDs across the life cycle for AHA (36) following the Polish (11, 42) and Cyprus priorities of the EU Council (43).

4- Understanding CRDs in elderly people: Care pathways for airway diseases (rhinitis, asthma and COPD) and their multimorbidities in elderly people need to identify prioritized questions and use ICT tools $(44,45)$. Public health initiatives are needed for the early identification of those presenting in a pharmacy to purchase treatment.

5- Multimorbidity in CRDs. To describe the clinical profile of patients with CRDs, the patterns of multimorbidity, and the use of health services in this group of patients based on the EpiChron cohort study (1.3M inhabitants).

6- Integrated care pathways for rhinitis across the life cycle and remote monitoring with a specific focus on seniors (44, 45).

7- Interactions between chronic respiratory diseases and frailty

8- Polymedication: In CRDs, and particularly in COPD, patient adherence is far from perfect. Most often, patients discontinue their treatment very soon after its initiation. Polymedication has profound medical and economical consequences.

9- Societal problems in CRDs will be initially tackled with the CARSAT (Caisse d'Assurance Retraite et Santé au Travail, Social Security, France) $(4,18)$ and scaled up to EU regions using the ICT tool on AHA (46-48).

10-Scaling up strategy, education, coaching and training (EUFOREA).

Contribution to the Scaling Up Strategy of the EIP on AHA: AIRWAYS ICPs is currently deployed in $25 \mathrm{EU}$ countries with national coordinations.

Expected Outcomes / Contribution to MAFEIP

1- All CRDs impact QOL severely across the life cycle. AIRWAYS ICPs is likely to have a major impact in seniors.

2- Novel care pathways including self-care, health and social carers that are patient-centered are required and represent one of the major objectives of AIRWAYS ICPs. Better knowledge of the patterns of multimorbidity in CRDs and the characteristics of health care use. 
3- Fit at work with rhinitis will have a major impact on economy.

\section{Embedding synergies in EIP on AHA Reference Sites}

Synergies have been built among EIP on AHA Reference Sites as examples of comprehensive, innovation-based approaches to AHA. EIP on AHA Reference Sites are coalitions of regions, cities, integrated hospitals or care organisations able to show a concrete impact of innovative practices, which could be transferred to other European contexts. A total of 32 Reference Sites have been awarded (1).

Reference Sites conscious of the need for synergies and a collaborative approach to address health and care challenges of an ageing population expressed the common will to establish a Collaborative Network to facilitate joint reflection and action in sharing and transferring best practice in the development and scaling up of health and care strategies, policies and service delivery models.

The interregional Reference Site Collaborative Network (RSCN) includes References Sites recognised by the Commission as well as Regions intending to apply for Reference Site status (candidate Reference Sites). Its main goal is to improve health and care through an active cooperation, contributing to the general debate with the EU institutions, in order to optimise the possibilities for sharing a strong, sustainable health and care system for all, while respecting the different competences and responsibilities in the direct organisation of the health and care services of the Member States and Regions.

\section{Support for the EIP on AHA Scaling up strategy}

The Scaling Up Strategy will follow the 5-step approach that has been proposed by the EIP on AHA and that has already been applied to AIRWAYS ICPs ((https://ec.europa.eu/ research/innovation-union/pdf/active-healthy-ageing/scaling up_strategy.pdf, Bousquet et al, submitted).

An up-scaling strategy is multidimensional and an accurate, appropriate and complete execution of each step is necessary to enable rigorous and systematic fulfilment of subsequent steps in the up-scaling process. As an example, up-scaling the IKINÄ (THL National Falls Prevention Initiative) guideline for fall prevention by THL (Terveyden ja Hyvinvoinnin Laitos, National Institute for Health and Welfare, Finland) in Finland (49) may be proposed. WHO's ExpandNet guides (50) to up-scaling may provide potential additions to the Scaling-up Strategy of the EIP on AHA's.

The dissemination was proposed to be carried out using the same model as previous B3 AG and/or AIRWAYS ICPs meetings $(36,39,43,46-48,51-55)$.

\section{Monitoring of activities carried out within the synergies}

\section{MAFEIP}

Monitoring the activities carried out within the EIP on AHA needs a flexible and consistent approach to estimate health and economic impacts across interventions and commitments. A generic and flexible web-based monitoring and assessment tool has been developed. The MAFEIP tool estimates health and economic outcomes in terms of incremental changes in Quality Adjusted Life Years (QALYs) as well as health and social care utilisation. The MAFEIP-tool can provide an early assessment of the likelihood that interventions will achieve the anticipated impact. It can also identify what drives the effectiveness or efficiency of interventions to guide further refinement, design upgrades and evaluation $(2,3)$.

\section{AHA operative questionnaire}

A core operational definition of AHA is needed to conduct comparisons (56). A conceptual AHA framework proposed by the RSCN includes several items such as functioning (individual capability and underlying body systems, wellbeing, activities and participation, and diseases (including non-communicable diseases, frailty, mental and oral health disorders) $(46,47)$. The instruments include core and optional domains/instruments depending on the needs and questions (48). A major common domain is function as measured by the World Health Organization Disability Assessment Schedule 2.0 (WHODAS 2.0) that can be used across all diseases and healthy individuals. It covers many of the AHA dimensions proposed by the RSCN. However, WHODAS-2.0 does not include all dimensions proposed for AHA assessment. The second common domain is Health-Related QOL (HRQL). EQ-5D is one of the QALY measurements and the AHA questionnaire is therefore interoperable with MAFEIP. The instrument is translated and culturally validated for most EU countries and will be digitalized in the first quarter of 2016. A report of the AHA questionnaire in the form of a spider diagramme will facilitate usual comparisons across individuals and groups of interest (56).

\section{Other tools}

Assessment scales, as information entities, are not often equipped with a rigorous typing of data. This disables the gap between logic and guidelines, not only in geriatric assessment (57) but also within municipal and regional decisionmaking in elderly care. Logic is, on the one hand, a carrier of information, and, on the other hand, it includes a mechanism for rigorous logical inference which underlies decisionmaking. Gerontological conditions and circumstances are about information and knowledge, and gerontological data can be properly typed to open up possibilities e.g. for comparative studies and development of regional and national repositories involving gerontological data and information (58).

The information structure representation of nomenclatures 


\section{JNHA: GERIATRIC SCIENCE}

and classifications is also important. WHO classifications are logically lative (59). The reference classifications ICD (International Classification of Diseases) and ICF (International Classification of Functioning, Disability and Health) then appear in structured relation with each other. Similar transformations can be made for the derived and related classifications ICPC-2, ICECI, ISO9999, ATC/DDD and ICNP (60).

These information entities are inherently multivalent, and classifications like the ICF explicitly recognize this multivalence through introduction of its generic scale. This, in turn, requires the formal management of many-valuedness and uncertainty in a logical setting (49).

\section{Conclusion}

AHA requires a multidimensional and multidisciplinary approach to allow people from multiple backgrounds to work together sharing a common language. The experience of different stakeholders working in a collaborative way producing concrete results in the different Action Groups sets a promising ground for the difficult challenge of scaling up good practices at European level.

The added value of working together requires identifying synergies not only between different good practices but also between different Action Groups result. To yield actual benefits, they have to be developed in concrete action plans that explain the rationale for the synergy, the participants, the objectives and a concrete plan with sprints.

EIP AHA implementation can manage a limited number of synergy actions. To select them, a flexible but structured process, with a transparent evaluation methodology, had to be used. The success of the first call, with nine proposals submitted and evaluated, supports the viability of the approach chosen. Eight of the proposals were selected.

New stakeholders have to join and new proposals need to be implemented. To ensure the added value of the whole process, Actions have to be assessed according to their estimated health and economic outcomes as well as health and social care utilisation using MAFEIP and other tools.

Conflict of interest: All the authors declare that they have no competing interest, except: BESCOS, BOUSQUET, BRIGHTLING, CESARI, DE BLAY, DE CARLO, DEMOLY, DJUKANOVIC, DU TOIT, JOHNSTON, KARDAS, KJERSTJENS,, KLIMEK, KUNA, MACNEE, MARTI, MULLOL, PEDERSEN, PLAVEC, POSTMA, ROCHE, VAN GANSE, VAN HAGE

\section{References}

1. Bousquet J, Michel J, Standberg T, Crooks G, Iakovidis I, Gomez M. The European Innovation Partnership on Active and Healthy Ageing: the European Geriatric Medicine introduces the EIP on AHA Column. Eur Geriatr Med. 2014;5(6):361-2.

2. Boehler CE, de Graaf G, Steuten L, Yang Y, Abadie F. Development of a web-based tool for the assessment of health and economic outcomes of the European Innovation Partnership on Active and Healthy Ageing (EIP on AHA). BMC Med Inform Decis Mak. 2015;15 Suppl 3:S4.

3. de Graaf G, Steuten L, Pecchia L, Boehler C. Early Health Economic Assessment in Innovation Partnerships: Lessons from the European Innovation Partnership on Active and Healthy Ageing. Value Health. 2015;18(7):A726.
4. Nogues M, Millot-Keurinck J, Iglesia-Gomez M, Alonso-Bouzon C, Bewick M, Bialoszewski A, et al. Active and Healthy Ageing: From health prevention to personal care. CARSAT-MACVIA 7 meeting Eur Geriatr Med. 2016:in press.

5. Podar T, Solntsev A, Reunanen A, Urbonaite B, Zalinkevicius R, Karvonen M, et al. Mortality in patients with childhood-onset type 1 diabetes in Finland, Estonia, and Lithuania: follow-up of nationwide cohorts. Diabetes Care. 2000;23(3):290-4.

6. Flood RG, Chiang VW. Rate and prediction of infection in children with diabetic ketoacidosis. Am J Emerg Med. 2001;19(4):270-3.

7. Wilson DP, Endres RK. Compliance with blood glucose monitoring in children with type 1 diabetes mellitus. J Pediatr. 1986;108(6):1022-4.

8. Lundberg B, Hansson L, Wentz E, Bjorkman T. Stigma, discrimination, empowerment and social networks: a preliminary investigation of their influence on subjective quality of life in a Swedish sample. Int J Soc Psychiatry. 2008;54(1):47-55.

9. Wong CK, Wong WC, Wan YF, Chan AK, Chan FW, Lam CL. Effect of a structured diabetes education programme in primary care on hospitalizations and emergency department visits among people with Type 2 diabetes mellitus: results from the Patient Empowerment Programme. Diabet Med. 2015.

10. Rosenfield S. Factors contributing to the subjective quality of life of the chronic mentally ill. J Health Soc Behav. 1992;33(4):299-315.

11. Samolinski B, Fronczak A, Kuna P, Akdis CA, Anto JM, Bialoszewski AZ, et al. Prevention and control of childhood asthma and allergy in the EU from the public health point of view: Polish Presidency of the European Union. Allergy. 2012;67(6):726-31.

12. Smallwood SW, Freedman DA, Pitner RO, Sharpe PA, Cole JA, Hastie S, et al Implementing a Community Empowerment Center to Build Capacity for Developing, Implementing, and Sustaining Interventions to Promote Community Health. J Community Health. 2015;40(6):1122-9.

13. Colombo C, Moja L, Gonzalez-Lorenzo M, Liberati A, Mosconi P Patient empowerment as a component of health system reforms: rights, benefits and vested interests. Intern Emerg Med. 2012;7(2):183-7.

14. Declaration and Programme of Action of the World Summit for Social Development, Draft Declaration, art. 26, par. o. 2011.

15. United Nations E-Government Survey 2010 "Leveraging E-government at a Time of Financial and Economic Crisis": Chapter 5 Citizen empowerment and inclusion. 2010.

16. Blain H, Leglise MS, Bernard PL, Dupeyron A, Pastor E, Strubel D, et al. Living lab MACVIA-LR Equilibre et Prévention des Chutes. Presse Med. 2015.

17. Bousquet J, Bourret R, Camuzat T, Augé P, Domy P, Bringer J, et al. Site de Référence MACVIA-LR (contre les maladies chroniques pour un vieillissement en bonne santé en Languedoc Roussillon) et Institut Euricap (European Institute fro Chronic Diseases, Ageing and Handicap). Presse Med. 2015;(suppl):in press.

18. Nogues M, Jeandel C, Touchon J, Pinto N, Blain H, Leglise M, et al. Living Lab Fragilité MACVIA-LR. Presse Med. 2015.

19. European Commission. «Options for Strengthening Responsible Research and Innovation - Report of the Expert Group on the State of Art in Europe on Responsible Research and Innovation» (PDF). doi:10.2777/46253. . 2013.

20. Owen R, Goldberg N. Responsible innovation: a pilot study with the U.K. Engineering and Physical Sciences Research Council. Risk Anal. 2010;30(11):1699707

21. Strand R, Bauer M, Hogan E, Revuelta G, Stagl S, Paula L, et al. Expert Group on Policy Indicators for Responsible Innovation. Indicators for promoting and monitoring Responsible Research and Innovation Report from the Expert Group on Policy Indicators. Luxembourg: Publications Office of the European Union, ISBN 978-92-79-43169-2, EUR 26866. 2015.

22. Blain $\mathrm{H}$, Abecassis $\mathrm{F}$, Adnet $\mathrm{P}$, Alomène $\mathrm{B}$, Amouyal $\mathrm{M}$, Bardy $\mathrm{B}$, et al. Living Lab Falls-MACVIA-LR: The falls prevention initiative of the European Innovation Partnership on Active and Healthy Ageing (EIP on AHA) in Languedoc Roussillon. Eur Geriatr Med. 2014;5(6):416-25.

23. Tinetti ME, Kumar C. The patient who falls: «It's always a trade-off». JAMA. 2010;303(3):258-66

24. Campbell AJ, Robertson MC. Implementation of multifactorial interventions for fal and fracture prevention. Age Ageing. 2006;35 Suppl 2:ii60-ii4.

25. Campbell AJ, Robertson MC. Fall prevention: single or multiple interventions? Single interventions for fall prevention. J Am Geriatr Soc. 2013;61(2):281-4; discussion 6-7.

26. Cawston H, Maravic M, Fardellone P, Gauthier A, Kanis JA, Compston J, et al Epidemiological burden of postmenopausal osteoporosis in France from 2010 to 2020: estimations from a disease model. Arch Osteoporos. 2012;7:237-46.

27. O'Caoimh R, Gao Y, Svendrovski A, Healy E, O'Connell E, O'Keeffe G, et al Screening for markers of frailty and perceived risk of adverse outcomes using the Risk Instrument for Screening in the Community (RISC). BMC Geriatr. 2014;14:104.

28. O'Caoimh R, Cornally N, Weathers E, O'Sullivan R, Fitzgerald C, Orfila F, et al. Risk prediction in the community: A systematic review of case-finding instruments that predict adverse healthcare outcomes in community-dwelling older adults. Maturitas. 2015;82(1):3-21.

29. Nishino Y, Gilmour S, Shibuya K. Inequality in diabetes-related hospital admissions in England by socioeconomic deprivation and ethnicity: facility-based cross-sectional analysis. PLoS One. 2015;10(2):e0116689. 


\section{SYNERGIES IN ACTIVE AND HEALTHY AGEING}

30. Newall N, McArthur J, Menec VH. A longitudinal examination of social participation, loneliness, and use of physician and hospital services. J Aging Health. 2015;27(3):500-18.

31. van Velsen L, Illario M, Jansen-Kosterink S, Crola C, Di Somma C, Colao A, et al. A Community-Based, Technology-Supported Health Service for Detecting and Preventing Frailty among Older Adults: A Participatory Design Development Process. J Aging Res. 2015;2015:216084.

32. Marazzi M, Inzerilli M, Madaro O, Palombi L, Scarcella P, Orlando S, et al. Impact of the Community-Based Active Monitoring Program on the Long Term Care Services Use and In-Patient Admissions of the Over-74 Population. Adv Ageing Res. 2015;4:187-94

33. Paul C, Teixeira L, Azevedo MJ, Alves S, Duarte M, O'Caoimh R, et al. Perceived Risk of Mental Health Problems in Primary Care. Front Aging Neurosci. 2015;7:212.

34. Mann E, Böhmdorfer B, Frühwald T, Roller-Wirnsberger R, Dovjak P, DückelmannHofer C, et al. Potentially inappropriate medication in geriatric patients: the Austrian consensus panel list. . Wien Klin Wochenschr. 2012;124(5-6):160-9.

35. Bousquet J, Khaltaev N. Global surveillance, prevention and control of Chronic Respiratory Diseases. A comprehensive approach. Global Alliance against Chronic Respiratory Diseases. World Health Organization. ISBN 9789241563468. 2007:148 pages.

36. Bousquet J, Anto JM, Berkouk K, Gergen P, Antunes JP, Auge P, et al. Developmental determinants in non-communicable chronic diseases and ageing. Thorax. 2015;70(6):595-7.

37. Bousquet J, Addis A, Adcock I, Agache I, Agusti A, Alonso A, et al. Integrated care pathways for airway diseases (AIRWAYS-ICPs). Eur Respir J. 2014;44(2):304-23.

38. Bousquet J, Mercier J, Avignon A, Bourret R, Camuzat T. MACVIA-LR (France) case study. Report EUR 27150 EN. In: Abadie F, editor. Strategic Intelligence Monitor on Personal Health Systems Phase 3 (SIMPHS3). JRC94487. Luxembourg: Publications Office of the European Union: JRC (Joint Research Centre ) Science and policy report; 2015. p. https://ec.europa.eu/jrc.

39. Bousquet J, Grouse L, Zhong N. The fight against chronic respiratory diseases in the elderly: the European Innovation Partnership on Active and Healthy Aging and beyond. J Thorac Dis. 2015;7(1):108-10.

40. Bousquet J, Khaltaev N, Cruz AA, Denburg J, Fokkens WJ, Togias A, et al. Allergic Rhinitis and its Impact on Asthma (ARIA) 2008 update (in collaboration with the World Health Organization, GA²LEN and AllerGen). Allergy. 2008;63 Suppl 86:8160 .

41. Chiron R, Caimmi D, Valiulis A, Durieu I, Tejedor P, Le Cam Y, et al. A model for active and healthy ageing with a rare genetic disease: cystic fibrosis. Eur Respir J. 2016;47(3):714-9.

42. Samolinski B, Fronczak A, Wlodarczyk A, Bousquet J. Council of the European Union conclusions on chronic respiratory diseases in children. Lancet. 2012;379(9822):e45-6.

43. Bousquet J, Tanasescu CC, Camuzat T, Anto JM, Blasi F, Neou A, et al. Impact of early diagnosis and control of chronic respiratory diseases on active and healthy ageing. A debate at the European Union Parliament. Allergy. 2013;68(5):555-61.

44. Bourret R, Bousquet J, J M, T C, Bedbrook A, P D, et al. MASK rhinitis, a single tool for integrated care pathways in allergic rhinitis. World Hosp Health Serv.
2015;51(3):36-9.

45. Bousquet J, Schunemann HJ, Fonseca J, Samolinski B, Bachert C, Canonica GW, et al. MACVIA-ARIA Sentinel NetworK for allergic rhinitis (MASK-rhinitis): the new generation guideline implementation. Allergy. 2015;70(11):1372-92.

46. Bousquet J, Kuh D, Bewick M, Strandberg T, Farrell J, Pengelly R, et al. Operational definition of active and healthy ageing (AHA): Framework concensus. J Nutr Health Aging. 2015;19(9):955-60.

47. Bousquet J, Kuh D, Bewick M, Strandberg T, Farrell J, Pengelly R, et al. Operational definition of active and healthy ageing (AHA): Report of the meeting held in Montpellier October 21,22-2012. Eur Geriatr Med. 2015;6(2):196-200.

48. Bousquet J, Malva J, Nogues M, Rodriguez-Mañas L, Vellas B, Farrell J, et al Operational definition of active and healthy ageing (AHA): The European Innovation Partnership (EIP) on AHA Reference Site questionnaire J Am Med Dir Assoc. 2015;16(12):1020-6.

49. Pajala S. Guideline for development and implementation of evidence based falls prevention and best practices. (In Finnish: Kehitä ja johda kaatumisten ehkäisyä. Opas toimintakäytäntöjen implementointiin). . THL, Kide 25, 2015 http://urnfi/ URN:ISBN:978-952-302-301-7. 2015.

50. Practical guidance for scaling up health service innovations. WHO. 2009:http:// whqlibdoc.who.int/publications/2009/9789241598521_eng.pdf

51. Bousquet J, Hajjam J, Piette F, Jean-Bart B, Wlosik C, Robine JM, et al. [The French reference sites of the European Innovation Partnership on active and healthy ageing]. Presse Med. 2013;42(12):1558-61.

52. Bousquet J, Rosado Pinto J, Barbara C, Correira da Sousa J, Fonseca J, Pereira Miguel J, et al. Portugal at the cross road of international chronic respiratory programmes. Rev Port Pneumol (2006). 2015;21(5):230-2.

53. Lodrup Carlsen KC, Haahtela T, Carlsen KH, Smith A, Bjerke M, Wickman M, et al. Integrated Allergy and Asthma Prevention and Care: Report of the MeDALL/ AIRWAYS ICPs Meeting at the Ministry of Health and Care Services, Oslo, Norway. Int Arch Allergy Immunol. 2015;167(1):57-64.

54. Muraro A, Fokkens WJ, Pietikainen S, Borrelli D, Agache I, Bousquet J, et al. European symposium on precision medicine in allergy and airways diseases: report of the European Union parliament symposium (October 14, 2015). Rhinology. 2015.

55. Muraro A, Fokkens WJ, Pietikainen S, Borrelli D, Agache I, Bousquet J, et al. European Symposium on Precision Medicine in Allergy and Airways Diseases: Report of the European Union Parliament Symposium (October 14, 2015). Allergy. 2015.

56. Malva JO, Bousquet J. Operational definition of active and healthy ageing: Roadmap from concept to change of management. Maturitas. 2016;84:3-4.

57. Burns A, Lawlor B, Craig S. Rating scales in old age psychiatry. Br J Psychiatry. 2002;180:161-7.

58. Eklund P, Immonen M, Petäkoski-Hult T, Similä H. The logic of geriatrics. J Nutr Health Ageing. 2013;17, suppl 1:S305-6.

59. Eklund P, Galán M, Helgesson R, Kortelainen J. Fuzzy terms. Fuzzy. Sets Syst. 2015;256:211-35.

60. Eklund P. Lative Logic Accomodating the WHO Family of International Classifications. In: Cruz-Cunha M, Miranda I, editors. Encyclopedia of E-Health and Telemedicine IGI Global; 2016. p. in press. 